UDC 619:616.98: 579.852.1

DOI: $10.21668 /$ health.risk/2021.1.11.eng

Research article

\title{
ANTHRAX CATTLE BURIALS AS A POTENTIAL THREAT CAUSED BY CHANGES IN CRYOLITE ZONES IN THE NORTHERN EUROPEAN PART OF RUSSIA
}

\author{
S.A. Iglovsky, V.V. Kriauciunas \\ N. Laverov Federal Center for Integrated Arctic Research of the Ural Branch of the Russian Academy of Sciences, \\ 109 Naberezhnaya Severnoi Dviny, Arkhangel'sk, 163000, Russian Federation
}

Over recent years there have been registered anthrax cases among animals and people in Russia. Anthrax cattle burials remain a basic risk factor that causes epizootic deterioration. A lot of such burials do not correspond to sanitaryepidemiologic requirements especially those located in zones where long-term frozen rocks are now being developed in the northern European part of the country.

Our research goal was to examine a situation with anthrax cattle burials in the chosen regions, especially bearing in mind climatic changes and changes in cryolite zones as well as to assess future prospects regarding them. It is especially vital for native people who live in tundra and breed their numerous deer herds there.

To achieve the goal, several tasks were accomplished. First, we performed preliminary analysis of anthrax cattle burials distribution in the northern European part of the country and places that were unfavorable as per anthrax. Then, locations of such zones were compared with available data on contemporary development of the cryolite zone in the northern European part of the country. It was necessary to assess future changes in the cryolite zone and describe occurring problems related to anthrax cattle burials being widely spread there as well as to suggest possible ways to solve them. Over the last 50 years considerable spots in the cryolite zone have thawed through completely or partially, especially in an area close to the south border of frozen earth. It is important to know an actual situation with anthrax cattle burials given changing climatic conditions and to assess their future prospects. In order to prevent emergencies in zones where geocryological processes have been activated it is necessary to measure temperature on anthrax cattle burials territories, to assess geocryological threats, to create mathematical models for probable negative events occurrence, as well as to accomplish certain anti-epidemic, anti-epizootic, and preventive activities.

Key words: anthrax cattle burials, risks, cryolite zone, seasonal-thawed layer, frozen earth degradation, thawing through, monitoring.

Recently there have been anthrax cases among people and animals registered in Russia. The disease was caused by contacts with infected animals being slaughtered without giving notice to veterinary services; by people treating animals' carcasses or burying corpses of animals that died due to anthrax; by people working with infected meat, treating sick ani- mals, or selling raw meat on markets. Anthrax cattle burials remain a risk factor that might cause epizootic ill-being related to anthrax since many of them do not conform to sanitary-epidemiologic requirements as it was mentioned in the works [1-12], especially in permafrost zones and zones prone to seasonal freezing ${ }^{1}$. These cattle burials can be destroyed

(C) Iglovsky S.A., Kriauciunas V.V., 2021

Stanislav A. Iglovsky - Candidate of Geographical Sciences, Leading researcher (e-mail: iglovskys@mail.ru; tel.: +7 (921) 240-80-08; ORCID: https://orcid.org/0000-0001-9675-455X).

Vidas V. Kriauciunas - Candidate of Geological and Mineralogical Sciences, Leading researcher (e-mail: vidas76@mail.ru; tel.: +7 (911) 068-15-76; ORCID: https://orcid.org/0000-0001-7437-381X).

${ }^{1}$ Osadchaya G.G., Tumel'N.V., Zengina T. Yu., Lapteva E.M. Survey geocryological map of Bolshezemelskaya tundra (Komi Republic and the Nenets Autonomous Area). Scaled 1:1,000,000. The project report issued within PROON/GEF/ES project Strengthening the system of natural protected areas in Komi Republic aimed at preserving biological diversity in primary forests located near the upper Pechora. Syktyvkar, Publishing house of the Komi SC of the RAS Urals Branch Publ., 2015, 112 p. (in Russian). 
due to permafrost thawing. In 2016 in the RF epidemiologic satiation with anthrax deteriorated. There was an anthrax focus registered in Yamal distirct of the Yamal-Nenets Autonomous Area; it occurred due to a significant epizooty among deer $[13,14]$. Anthrax epizooties are annually registered among farm and wild animals in Asia, Africa, and South America and it often results in wide-scale outbreaks among people. A large anthrax outbreak was detected in May-June 2017 in India, Pakistan, and Bangladesh [15]. Animals get infected with anthrax mostly due to grazing in sanitary protected zones near anthrax cattle burials and fodder procuring in such areas. Another significant role belongs to cattle vaccination and its scales as they should cover all livestock. The infection potential is enhanced by significant number of soil foci that can represent a threat for a long time and cause periodical outbreaks among farm animals and people. But the greatest threat for people and animals is created by anthrax cattle burials. There are approximately 35 thousand stationary soil foci on the territory of Russia where the situation with anthrax is rather adverse; 7,940 out of them are cattle burials [9].

Over the last 50 years substantial areas in the cryolithozone located in the European northern part of the country have thawed either completely or partially; it is especially true for zones located near the southern permafrost zone border.

Our research goal was to get a clear picture of the current situation with anthrax cattle burials located in this zone, especially given the climatic changes occurring at the moment and their influence on the cryolithozone; another goal was to estimate their future condition. It is important for native people who live in tundra and breed their numeral deer herds three. To achieve these goals, we had to solve the following tasks. First, we performed preliminary analysis of anthrax cattle burials prevalence in the European northern part of the country and places where a situation was adverse as per anthrax. Locations of such land spots that were partially shown on the epizootic map of the Nenets Autonomous Area ${ }^{2}$ were compared with available data on the current situation in the cryolithozone located in the European northern part of the country ${ }^{1}$ [16-21]. It was necessary to estimate future changes in the cryolithozone and highlight new arising problems associated with anthrax cattle burials prevalence in the region and to suggest ways to solve them.

Data and methods. We have performed cartographic analysis of several permafrost maps drawn as per actual and predicted data; the results allow us to conclude that there has been significant «restructuring» of geocryological conditions existing in the European northern part of Russia [16-21]. This restructuring involved southern borders of the permafrost zones moving dozen kilometers to the north as well as a significant increase in capacity of blind-end taliks that had been existing prior to the examined period; there was also a decrease in permafrost area due to new taliks occurring, a substantial rise in permafrost temperature, and thermal karst slumps development [17, 22, 23]. Permafrost degradation predicted by 2020 will be much less apparent than over 1970-2005; but after 2020 we can expect greater permafrost degradation due to heating effects produced by growing greenhouse gases emission from permafrost [24].

Results and discussion. Temperature is a most significant property that determines condition of the cryolithozone. Thus, the greatest changes in permafrost temperatures (increase by $0.6-1{ }^{\circ} \mathrm{C}$ ) occur in the eastern part of the Nenets Autonomous Area and Komi Republic (Urals, Pai-Khoi). Here we should pay close attentions to several districts that are unfavorable in terms of anthrax spread; they are river basins of Malaya Usa, Bolshaya Syr'yaga, Khal'mel'shor (Komi), Yunkoshor, areas close to the Kara bay, and Tab'yu river (The Nenets Autonomous Area) [19].

\footnotetext{
${ }^{2}$ The epizootic map of the Nenets Autonomous Area. Naryan-Mar, OGU NAO The Nenets Information-Analytical Center Publ., 2010.
} 
0.4-0.6 ${ }^{\circ} \mathrm{C}$ temperature rise in permafrost occurs on territories located to the east from Porchtyvys and Syadeyu rivers. There are also areas here that are adverse as per anthrax; they are river basins of Porchtyvys, Syadeyu, Adz'va, Pyayu, areas close to Vashutkiny lakes, Savauy, Syarnayu, Yareyu, and Ynkoshor rivers.

$0.2-0.4{ }^{\circ} \mathrm{C}$ temperature rise in permafrost has been detected practically on the whole Nenets Autonomous Area territory excluding the Pechora bay shore and the Barents sea shore where temperature will grow only slightly, less than by $0.2^{\circ} \mathrm{C}$. Thus, an ascending trend in average annual rock temperature detected at the Bolvanskiy stationary post amounted to $0.04{ }^{\circ} \mathrm{C} /$ per year on average for different landscapes. In 1980-ties, average annual permafrost temperature taken at 10 meters deep underground changed from -0.8 to $-2.5^{\circ} \mathrm{C}$, and then grew by $0.2 \ldots 1.2{ }^{\circ} \mathrm{C}$, and a range of changes in average annual permafrost temperature in different landscapes decreased by almost 3 times and now amounts to $-0.6 \ldots-1.2^{\circ} \mathrm{C}$. Layers prone to seasonal thawing thawed more considerably in the southern tundra close to the Bolvanskiy stationary post, starting from 2000, from 1.2 meters (2000) to 1.8 meters (2016). The latter figure is greater than potential freezing depth in this region; it indicates that permafrost roof has started to go down [21]. From 2005 to 2020 thawing depth varied from 1 to 2 meters near Vashutkiny lakes and the western Adz'va river basin; up to 1 meter, near Korataikha river; up to 2 meters, near Yun'yakha and Yareyu river; from 2 to 4 meters, near Ynkoshor river; up to 1 meter, near the Kara bay; up to 1 meter, near Tab'-Yu river.

In the northern part of the Nenets Autonomous Area (the Barents and Kara sea shore) sporadic talik zones might occur in areas that are adverse as per anthrax. These areas include zones located to the south from the Bolvanskaya bay, Urer'yakha and Ynkshor rivers, and Amdermy settlement (thawing depth is up to 1 meter).

Permafrost cartographic analysis allows stating the following. Firstly, over 1970-2020 there has been a substantial decrease in holo- cene permafrost that goes down from the earth surface and that has thawed completely in the southern regions; this fact should be taken into account when anthrax cattle burials are estimated. As a result, the southern border of this permafrost area has moved to the north by 30 $40 \mathrm{~km}$ on the Pechora lowlands and the Kanin peninsula; on the Priuralye mounting plains the border has moved as far as $80 \mathrm{~km}$ to the north $[18,19]$. Secondly, multiple firn blindend taliks have occurred in areas between rives in non-continuous permafrost zone and southern parts of continuous permafrost. This fact, together with temperature rise in permafrost up to minus $2{ }^{\circ} \mathrm{C}$ and even higher allows stating that borders of non-continuous and continuous permafrost have moved to the north by $15-20 \mathrm{~km}$ in the lowland tundra and many dozens $\mathrm{km}$ in the Priuralye and PaiKhoi [18]. Thirdly, rise in permafrost temperature that occurs almost everywhere has resulted in thermal karst processes being activated also almost everywhere within landscapes created by quaternary mineral deposits [20].

Having analyzed the situation with permafrost and anthrax spread in the Nenets Autonomous Area over a period from 1970 to 2010, we can make certain assumptions on its future prospects. Territories with their foundation being sand deposits that had long been frozen permanently accounted for a substantial part of the Nenets Autonomous Area located its border with Komi Republic. They thawed practically completely or partially over a period from 1970 to 2020 . This zone includes territories located to the south-east from Naryan-Mar city and areas where anthrax occurs and spreads are spotted in it. These areas are vicinity of Naryan-Mar, basins if Kuya, Voyvozh, Belaya-Yu, Norbein-Yu, KhalmerYu, Kolva, Kolvavis, Paivis, Neruyu, Vomles'yu, Kharutayu, and Leviy Foma-Yu rivers. Geocryological situation has changed considerably on this territory as it has become more watery and boggy and cryogenic processes have been activated there. A significant part of continuous permafrost in the Nenets Autonomous Area (located along the line between 
Naryan-Mar and Vashutkiny lakes, $68^{\circ}$ n.1.) transformed into non-continuous one over 1970-2020 as it became apparent via talik zones occurrence. Thus, from 1970 to 2020 thawing depth varied from 6 to 8 meters near Tedin'yakha, Pekhekheyakha and Urenyakha rivers (areas that are adverse as per anthrax); from 4 to 6 meters near Vashutkiny lakes; from 8 to 9 meters, in the western part of Adz'va river; from 5 to 7 meters, near Kortaraikha river; from 6 to 10 meters, near Yun'yakha and Yareyu rivers; from 6 to 12 meters, near Yunkshor river; from 5 to 7 meters, near the Kara bay; from 4 to 6 meters, near Tab'-Yu river.

In Arkhangelsk region there have been no anthrax cases among people registered for more than 80 years in areas that are prone to seasonal freezing [25]. The last anthrax case among animals (a pig) was registered in Uima settlement located in Primorskiy region. There are 24 anthrax cattle burials in Ark- hangelsk region. It is unclear who is responsible for 8 of them, including 4 burials located in Krasnoborskiy district; 2 burials, Nyandomskiy district; 1 burial in Onezhskiy district and 1 burial in Pinezhskiy district. Unfavorable epizootic situation in terms of anthrax creates a threat that infected animals or raw materials and agricultural products that contain anthrax agent spores can be brought to Arkhangelsk region.

Today in Arkhangelsk region there are 113 cattle burials (biothermal pits), 24 of them being anthrax burials. All anthrax cattle burials conform to veterinary and sanitary requirements. At the present tedious work is being performed both in Russia in general and Arkhangelsk region in particular aimed at maintaining anthrax cattle burials and biothermal pits in proper veterinary and sanitary condition. Animals are vaccinated against anthrax in areas that are adverse as per this factor (Table).

Table

Municipal districts in Arkhangelsk region where anthrax cattle burials are located (taken as per March 20, 2009)

\begin{tabular}{|c|c|c|c|c|c|}
\hline \multirow[b]{2}{*}{ Municipal district } & \multicolumn{2}{|c|}{ Overall number of burials } & \multicolumn{3}{|c|}{ Cattle burials } \\
\hline & $\begin{array}{c}\text { Location } \\
\text { not detected }\end{array}$ & $\begin{array}{c}\text { Location } \\
\text { not detected }\end{array}$ & Closed & Operating & Anthrax burials \\
\hline Arkhangelsk & 1 & - & - & - & - \\
\hline Velskiy & 7 & 19 & 11 & 8 & 9 \\
\hline Verkhnetoemskiy & - & 15 & 11 & 4 & - \\
\hline Vilegodskiy & - & 7 & - & 7 & - \\
\hline Vinogradovskiy & - & 7 & 4 & 3 & 1 \\
\hline Kargopolskiy & 8 & 10 & 2 & 8 & - \\
\hline Konoshskiy & 1 & 3 & 2 & 1 & 2 \\
\hline Kotlasskiy & 1 & 6 & 2 & 4 & 1 \\
\hline Krasnoborskiy & 11 & 11 & 4 & 7 & 4 \\
\hline Lenskiy & - & 3 & 2 & 1 & - \\
\hline Leshukonskiy & - & 7 & - & 7 & - \\
\hline Mezenskiy & - & 8 & 1 & 4 & 1 \\
\hline Nyadomskiy & 2 & 5 & 2 & 3 & 2 \\
\hline Onezhskiy & - & 2 & 1 & 1 & 1 \\
\hline Pinezhskiy & - & 1 & 1 & - & 1 \\
\hline Plesetskiy & 2 & 8 & 2 & 6 & - \\
\hline Primorskiy & - & 4 & - & 4 & - \\
\hline Ust'yanskiy & 2 & 5 & 1 & 4 & - \\
\hline Kholmogorskiy & - & 12 & 3 & 9 & 1 \\
\hline Shenkurskiy & - & 20 & 7 & 13 & 1 \\
\hline Total & 35 & 150 & 56 & 94 & 24 \\
\hline $\begin{array}{l}\text { The Nenets } \\
\text { Autonomous Area }\end{array}$ & 19 & - & - & - & - \\
\hline
\end{tabular}


Conclusion. In our opinion, it is necessary to continue complex monitoring examinations of anthrax cattle burials in potentially hazardous areas where geocryological processes are activated [14, 19, 26]. Unregistered anthrax cattle burials can cause a growth in epidemic outbreaks and a good example here is an emergency that occurred in the YamalNenets Autonomous Area. To reduce the detected risks, it is necessary to bind unregistered anthrax cattle burials to geographic maps as it was done in Stavropol region with the use of a geoinformation system [27].

At present geocryological conditions in the European northern part of Russia are changing considerably. The southern borders of continuous permafrost and cryolithozone are moving dozens $\mathrm{km}$ to the north [28]. There is a considerable growth in capacity of blind-end taliks that have existed before and permafrost area is declining due to new taliks occurrence; there is also a considerable increase in permafrost temperature and thermal karst slumps are developing. It all may lead to anthrax cattle burials destruction, especially in vulnerable tundra zones, both in permafrost areas and areas prone to seasonal freezing. Anthrax spores can be released from thawing layers in these areas where annually many thousands deer migrate from north to south and back. A serious problem here is low awareness among native population about risks caused by anthrax. Besides, permafrost degradation, combined with factors related to human activities (for example, oil and gas extraction), brings about changes in culture and traditions of native deer-breeding communities; it may result in changing routes and periods of deer grazing. When accomplishing complex monitoring, it is necessary to examine deer-breeding communities movements, animal migration routes, and anthrax spores penetration into seasonal-thawing layers caused by permafrost degradation. Such an approach, combined with monitoring over seasonal-thawing layers and permafrost in areas where the risks are the highest and studies on anthrax contagion in the European northern part of the country, can be useful for determining mechanisms of the disease spread in the Arctic regions and ultimately for taking relevant targeted preventive measures. In order to prevent emergencies in zones where geocryological processes are activated it is necessary to accomplish preventive temperature measurements on territories where cattle burials are located, to assess geocryological threats, and to create mathematical models for predicting negative events. It is also necessary to accomplish certain antiepidemic, anti-epizootic, and preventive activities.

Funding. The research was accomplished due to financial support provided by Russian Scientific Fund Grant No. 20-77-10057 «Diagnostics of permafrost degradation basing on isotope tracers $(234 \mathrm{U} / 238 \mathrm{U}, \delta 18 \mathrm{O}+\delta 2 \mathrm{H}, \delta 13 \mathrm{C}+14 \mathrm{C}) »$, the project supervised by E.Yu. Yakovlev, Candidate of Geological and Mineralogical Sciences.

Conflict of interests. The authors declare there is no any conflict of interests.

\section{References}

1. Gavrilov V.A. Biologicheskaya opasnost' sibireyazvennykh skotomogil'nikov i perspektivy resheniya sushchestvuyushchei problemy [Biological threat caused by anthrax cattle burials and prospects of finding solution to the existing problem]. Zhizn' bez opasnostei. Zdorov'e. Profilaktika. Dolgoletie, 2008, no. 4-1, pp. 81-84 (in Russian).

2. Bulgakova T. Climate change, vulnerability and adaptation among Nenets reindeer herders. Community Adaptation and Vulnerability in Arctic Region, 2010, pp. 83-105. DOI: 10.1007/97890-481-9174-1

3. Revich B.A., Podolnaya M.A. Thawing of permafrost may disturb historic cattle burial grounds in East Siberia. Glob. Health Action, 2011, no. 4, pp. 8482. DOI: 10.3402/gha.v4i0.8482

4. Revich B., Tokarevich N., Parkinson A.J. Climate change and zoonotic infections in the Russian Arctic. Int. J. Circumpolar Health, 2012, no. 71, pp. 18792. DOI: 10.3402/ijch.v71i0.18792 
5. Simonova E.G., Galkin V.V., Loktionova M.N., Ladnyi V.I. Anthrax cattle burial grounds in Russia and their biosafety. Zhurnal mikrobiologii, epidemiologii i immunobiologii, 2010, no. 4, pp. 23-26 (in Russian).

6. Simonova E.G., Kartavaya S.A., Loktionova M.N., Ladnyi V.I. Epidemiological hazard of anthrax animal burials: theoretical and methodological aspects. Meditsina v Kuzbasse, 2013, vol. 12, no. 2, pp. 26-31 (in Russian).

7. Kangbai J., Momoh E. Anthropogenic climatic change risks a global anthrax outbreak: a short communication. J. Trop. Dis, 2017, vol. 5, no. 4, pp. 2. DOI: 10.4172/2329-891X.1000244

8. Walsh M.G., de Smalen A.W., Mor S.M. Climatic influence on anthrax suitability in warming northern latitudes. Sci. Rep, 2018, vol. 18, no.8 (1), pp. 9269. DOI: 10.1038/s41598-018-27604-w

9. Koval'chuk N.A. Siberian cattle burial grounds: actual problems. Izvestiya Rossiiskoi Voennomeditsinskoi akademii, 2019, vol. 1, no. S1, pp. 214-216 (in Russian).

10. Dugarzhapova Z.F., Chesnokova M.V., Ivanova T.A., Kosilko S.A., Balakhonov S.V. Improvement of methodical approaches to investigation of anthrax burials and animal burial sites. Problemy osobo opasnykh infektsii, 2019, no. 4, pp. 41-47 (in Russian).

11. Dyagilev G.T., Chernyavskii V.F., Egorov I.Ya., Sofronova O.N., Nikiforov O.I. Epizootological and epidemiological monitoring of anthrax in the arctic and eastern zones of Yakutia. Prirodnye resursy Arktiki i Subarktiki, 2019, vol. 24, no. 2, pp. 95-105 (in Russian).

12. Hueffer K., Drown D., Romanovsky V., Hennessy T. Factors Contributing to Anthrax Outbreaks in the Circumpolar North. EcoHealth, 2020, vol. 17, pp. 174-180. DOI: 10.1007/s10393-020-01474-z

13. Selyaninov Yu.O., Egorova I.Yu., Kolbasov D.V. Anthrax in Yamal: reemergence causes and diagnostic issues. Veterinariya, 2016, no. 10, pp. 3-7 (in Russian).

14. Suranova T.G., Prosin V.I., Seminog V.V., Goryacheva N.G., Avitisov Anthrax P.V. in Yamal: results of liquidation of consequences of emergency situation. Meditsina katastrof, 2017, vol. 97, no. 1, pp. 38-42 (in Russian).

15. Terebova S.V. The monitoring of anthrax outbreaks. Agrarnyi vestnik Primor'ya, 2017, vol. 8, no. 4, pp. 42-47 (in Russian).

16. Oberman N.G., Mazhitova G.G. Permafrost dynamics in the north east of European Russia at the end of the $20^{\text {th }}$ century. Norsk Geografisk Tidsskrift, 2001, vol. 4, no. 55, pp. 241-244. DOI: $10.1080 / 00291950152746595$

17. Vechnaya merzlota i osvoenie neftegazonosnykh raionov [Frozen earth and oil-and-gas-bearing regions development]. In: E.S. Mel'nikova, S.E. Grechishcheva eds. Moscow, GEOS Publ., 2002, 402 p. (in Russian).

18. Oberman N.G., Shesler I.G. Sovremennye i prognoziruemye izmeneniya merzlotnykh uslovii Evropeiskogo severo-vostoka Rossiiskoi Federatsii [Contemporary and predicted changes in frozen earth in the north-east European part of the RF]. Problemy Severa i Arktiki Rossiiskoi Federatsii: nauchnoinformatsionnyi byulleten', 2009, no. 9, pp. 96-106 (in Russian).

19. Iglovsky S.A. Anthropogenic changes of permafrost in the European north and their consequences. Water Resources, 2014, vol. 41, no. 7, pp. 865-871. DOI: 10.1134/S0097807814070069

20. Osadchaya G.G., Tumel' N.V., Koroleva A.M. Morphological structure of cryogenic landscapes of the Bolshezemelskaya tundra. Kriosfera Zemli, 2016, vol. 20, no. 3, pp. 14-23 (in Russian).

21. Vasil'ev A.A., Gravis A.G., Gubar'kov A.A., Drozdov D.S., Korostelev Yu.V., Malkova G.V., Oblogov G.E. [et al.]. Permafrost degradation: results of the long-term geocryological monitoring in the western sector of Russian Arctic. Kriosfera zemli, 2020, vol. 24, no. 2, pp. 15-30 (in Russian).

22. Perel'shtein G.Z., Pavlov A.V., Buiskikh A.A. Changes in the permafrost zone upon the modern climate warming. Geoekologiya. Inzhenernaya geologiya, gidrogeologiya, geokriologiya, 2006, no. 4, pp. 305-312 (in Russian).

23. Biskaborn B.K., Smith S.L., Noetzli J., Matthes H., Vieira G., Streletskiy D.A., Schoeneich P. [et al.]. Permafrost is warming at a global scale. Nature Communication, 2019, vol. 16, no. 10 (1), pp. 264. DOI: 10.1038/s41467-018-08240-4

24. Turetsky M.R., Abbott B.W., Jones M.C., Walter Anthony K., Olefeldt D., Schuur E.A.G., Koven C. [et al.]. Permafrost collapse is accelerating carbon release. Nature, 2019, vol. 569, no. 7754, pp. 32-34. DOI: 10.1038/d41586-019-01313-4 
25. Iglovskii S.A., Shavrina E.V., Shvartsman Yu.G. Razvitie geokriogennykh protsessov na territorii Belomorsko-Kuloiskogo plato Arkhangel'skoi oblasti [ Geocryological processes development on the Belomorsko-Kuloyskoye plateau in Arkhangelsk region]. Materialy nauchno-prakticheskoi konferentsii, posvyashchennoi 25-letiyu GPZP Arkhangel'sk, 1999, pp. 52-54 (in Russian).

26. Stella E., Mari L., Gabrieli J., Bertuzzo E. Permafrost dynamics and the risk of anthrax transmission: a modelling study. Sci. Rep., 2020, no. 10, pp. 16460. DOI: 10.1038/s41598-020-72440-6

27. Buravtseva N.P., Mezentsev V.M., Ryazanova A.G., Golovinskaya T.M., Degtyarev D.Yu., Pazenko A.N., Semenova O.I., Kulichenko A.N. Use of geographic information systems for creation of electronic database of anthrax burial sites in the Stavropol territory. Problemy osobo opasnykh infektsii, 2019, no. 4, pp. 31-36 (in Russian).

28. Oberman N.G., Lygin A.M. Prognosis of the degradation of permafrost in an example of European north-east of Russia. Razvedka i okhrana nedr, 2009, no. 7, pp. 15-20 (in Russian).

Iglovsky S.A., Kriauciunas V.V. Anthrax cattle burials as a potential threat caused by changes in cryolite zones in the Northern European part of Russia. Health Risk Analysis, 2021, no. 1, pp. 108-114. DOI: 10.21668/health.risk/2021.1.11.eng

Received: 04.12.2020

Accepted: 03.03.2021

Published: 30.03 .2021 